\title{
Reconceptualising and Locating the Succinct Niche of the Practice of Female Circumcision Rite in Africa: A Literature Review
}

\author{
Prof. S. M. Kang'ethe \\ University of Fort Hare, Department of Social Work and Social Development, \\ Private bag X1314, ALICE. 5700, South Africa \\ Email: skangethe@ufh.ac.za \\ Mr Festus Khayundi \\ Department of Library Services, P/B X1314, Alice \\ Email: Khayundi@ufh.ac.za
}

Doi:10.5901/mjss.2014.v5n27p1335

\begin{abstract}
Advisedly and visionary, cultures need to be examined, and re-examined holistically to avoid unwarranted and skewed judgement against them, especially from the outsiders. Regrettably, subjective and dishonest treatment of African cultures especially by the west and some African elites have cost Africans their cultures, almost leading to their demise. It is critical, therefore, that a new dawn is ushered in to effectuate and reclaim cultural revival, cultural renaissance, cultural autonomy and emancipation that will reposition cultures such as female circumcision in their rightful niche. This article aims to reconceptualise and locate the cultural of female circumcision in its rightful niche. The article has used a review of literature methodology. Findings indicate that: the culture of female circumcision has immense social capital that could be used to facilitate behavioural change and therefore address social ills such as HIVIAIDS and moral decadence; It needs to be respected by reconceptualising it a new by referring it as female genital operation or surgery; discard retrogressive terminologies such as FGM/C/ torture etc; needs to be understood from "insider' lenses as opposed to the "outsider" lenses. The article recommends to the governments of Africa to respect the rite and lift the ban; allow people to enjoy their cultural rights; facilitate the removal of retrogressive issues surrounding the rite such as clinical hazards or mishaps; carry out holistic research on the rite to determine its positive and negative aspects.
\end{abstract}

Keywords: Female genital surgery, Female genital operation, moral decadence, cultural renaissance, imperialism, colonialism, insider lenses, outsider lenses.

\section{Problem Statement}

Skewedly and unfairly, African cultures have suffered disdain, condencesion, oppression and condescension especially from the western nations; and worse more from the African governments, scholars, elites and leaders who mistakenly associate development and modernization as a disregard of African cultures at the expense of the Western cultures. These cultural architects believe that this kind of an attitude towards cultures such as female circumcision need to change and different stakeholders to accept to examine and re-examine them holistically. Such a holistic autopsy of it could bring out all the progressive aspects to inform the immense social capital embedded in it; and also single out all the retrogressive aspects and carve a way forward to address them. This, these cultural architects believe could give the rite of female circumcision its dignity and people can practice it as they wish to enjoy their cultural rights enshrined in many countries' constitutions and bill of rights.

\section{Methodology}

The article is a discourse one and has elicited debates on the value of the rite of female circumcision, convincing every "Dick and Harry" why the rite should not be outlawed as it is embedded with immense social capital. The article has immensely benefitted from the writings of cultural architects, journals, books etc. 


\section{Introduction}

In recent times the rite of female circumcision (variously referred to as female genital mutilation, female genital cutting, female genital operation, female genital surgery, female torture, etc) as currently practised in Africa, the Middle East, and parts of Asia has elicited a lot of debates, discourses and researches in order to establish its rightful niche (Obermeyer, 1999). Critically and surprisingly, the debates, researches and commentaries emanating predominantly from Western scholars, medical practitioners, human rights activists, feminists, policy makers, and the media are notably skewed carrying pangs of biases as their tone reveals unconcealed condemnation of the rite of female circumcision in Africa and elsewhere the practice exists. Undoubtedly, the debates haves been instrumental on the policy stances taken by the United Nations Organization through its agencies such as the World Health Organisation (WHO) and the United Nations Children's Fund (UNICEF) (Boyle and Corl 2010; Lyons 2007). This has unfairly led to orchestrated campaign against female circumcision, almost exclusively from the West leading to polarized debate between the 'them' and 'us'. 'Us' (read Western) are telling 'them' (read Africa and other places where female circumcision is currently practiced) that they have sufficient knowledge to show that female genital mutilation is a horrid phenomenon, is barbaric, unsanitary, uncivilised and is a health hazardous practice that is performed using crude instruments such as rusted razor blades, broken bottles and even stones by people who are not trained and devoid of modernised knowledge befitting such kind of a bodily operation. The 'Us' continue to tell 'them' that they know the body of an African woman and being circumcised deprives an African woman her normal sexual and reproductive function (de Vries, 2012; Edouard et al, 2013).

According to 'Us', female circumcision is a tragic health and a human rights violation issue and 'them' must put in place a legislation to criminalize the practice. This sounds quite condescending and these researchers support and agree with those scholars from 'them' who consider the knowledge from 'Us' about female circumcision in Africa to be nothing other than a form of epistemological imperialism (Nnaemeka, 2005). The stance by the West to champion the course of female circumcision in Africa presents a great challenge to African scholars who must identify this as a niche that requires individual and concerted action by African scholars to effectuate cultural emancipation. This is because in these researchers' contention, the message presented about female circumcision in tandem with many other African cultures is that they are barbaric, naïve, and devoid of civilization (Kang'ethe, 2009). They also indicate that the culture should be driven into a state of extinction or annihilated altogether. Ironically and to the contrary, this a rite of passage which some parts of Africa consider invaluable and its total condemnation, especially from outsiders, is misplaced, erroneous, condescending, and demeaning. Perhaps this has happened because most of these messages emanates from the West, or assumes an outer perspective as opposed to an insider perspective. The messages have therefore embraced an ethnocentric stance or Eurocentric paradigm. There is therefore the need for a paradigm shift to situate the culture in its succinct niche and reality. These researchers contend that African or 'insider' discourse is likely to be more Afrocentric. Regrettably, studies done 'from within' are still far too few and infrequent to give the required platform for discourse based on Afrocentric paradigm. Perhaps this explains this form of cultural oppression that need to be addressed by African themselves (obermeyer, 1999).

\section{The Place and Niche of Female Circumcision in Societies Practising It}

\subsection{It is as an invaluable rite of passage}

Indubitably, female circumcision like male circumcision falls into the inventory of innumerable cultures that Africans, as in many other communities of the world embrace and cherish (Kang'ethe, 2013; Wodenmicael, 2009; Prazak 2007; Mbiti 1969). Importantly, female circumcision has been one of the rites of passage demarcating the stage of development in which the girl child passes into mature hood ( Kratz, 2003; Shweder 2000). Perhaps it is good to point out that in most African societies, one is born, lives, and dies within the appropriate rites of passage. That can take the form of circumcision, piercing of the nose, ears, lips, teeth extraction, cutting of certain fingers, tattooing, etc. (Kang'ethe, 2009, 2013; Wodenmicael, 2009; Mbiti 1969). The painful process that is usually associated with the practice, or the marks that are left behind after going through the rite may denote, among others, age group, social status, increase in sexual attraction, and a woman's chastity before marriage. Female circumcision, therefore, has immense social capital that societies practising the norm cherish and find bliss in (Kang'ethe, 2014a Ahmadu 2000; Prazak 2007). Inarguably, and in societies that uphold the rite, it is a part of societal functions that determines the totality of a woman or the stage in which a mature girl child may be called a mature woman, either psychologically, intellectually, emotionally and socially (Piaget, 1990; Gruenbaum, 2001). Perhaps it's good to point out that most of these practices coincide with the psychological stage of biological puberty. This is because girls usually undergo this rite at the age of 12-14 years (Kang'ethe, 2013). It 
is usually a key to important domains of life such as marriage and confers confidence and self-esteem to a woman who undergoes the rite (Shweder, 2000). In these researchers' thinking, this is one of the cultures whose attrition under the impacts of modernization, westernization and eurocentrism takes away the "Africanism" in the life of Africans. This, according to these researchers, should be a wakeup call to African scholars to rise to the challenge of defending these cultures by unearthing and bringing to the fore all the meanings espoused to the practice, as well as explain and demonstrate the invaluable social capital embedded in the practice. This, these researchers cum cultural architects believe is the dawn of cultural revival, emancipation, democracy, renaissance as well as repositioning the cultures in their succinct niches (Kang'ethe, 2013, 2014a).

Regrettably, perhaps the current generation in many African countries has been denied knowledge of the practice and the social capital inherent in it because of skewed information packaging and messaging, usually from the outsiders, or those with ethnocentric approaches devoid of the salt of Afrocentrism that it should portend. This denial and destruction of the culture was largely achieved through the process of colonialism (Mbiti, 1969). Among the designs of colonization was the total acculturation of the people of Africa. Unashamedly and unfairly, both the colonial administrators and the missionaries were bent on eliminating all forms of African culture including female circumcision. To this end, Gruenbaum (2005: 433-4) observes that during the colonial administration, the theme for many social change efforts was enlightenment, drawing the subject peoples out of traditions that Europeans deemed harmful, beliefs considered nonWestern, and practices that obstructed the smooth administration of colonial political and economic control... campaigns against indigenous rituals (e.g, scarification as a rite of passage into manhood, female genital cutting), ... were common under colonial powers'.

The scenario by Gruebaum (2005: 433) above points clearly that destruction of the African cultures was not because there was something wrong with the cultures, but African cultures fell victim of a larger capitalistic scheme by the western countries to achieve colonial leadership, hegemony and imperialism (Mbiti, 1969).

\subsection{Tenacity of female circumcision}

Perhaps the litmus test of a cultural strength is its continued existence and legacy despite efforts to annihilate it altogether. Indubitably, it is crystal clear that the culture of female circumcision has been under huge siege, socially and policy wise, especially with the wind of modernization, euro centrism, human rights activism, feminism and current globalization (Kang'ethe, 2014a). However and ironically, and despite spirited efforts by colonialism to obliterate African cultures, some of them persisted albeit clandestinely (Kang'ethe, 2013). This includes but not exclusive to circumcision of both men and women. At the time when Africa and the Africans are feeling that these rites defined what an African was, there is then the urgent need for the resuscitation of these cultural rites (Kang'ethe, 2014b). However, these researchers would be unrealistic to expect these cultural rites to be revived in the same state they were practised before their proscription. Admittedly, some of the rites may have had aspects that could be incompatible with current environment but it is argued that they still have some invaluable aspects that could be harnessed and incorporated into the existing culture. Perhaps it is admissible that the readers, or the cultural adherents accept that given the dynamic nature of any culture, some of the goal posts as well as the social capital embedded in them may have to shift.

\subsection{Conceptualizing the concept of female circumcision}

Perhaps the succinct value and social capital embedded in the cultural rite of female circumcision cannot be clear if it's meaning and what it stands for is not adequately conceptualized (Kang'ethe, 2014c). Succinct conceptualization will help change the minds of the detractors who see the practice as one with perfidious ramifications. Largely, female circumcision is not an exclusive African cultural practice. Regrettably and unfortunately, most scholars of the female circumcision practice tend to wink at the genesis of female circumcision and portray it as an African cultural practice. This has had an effect to imperialists and doomsayers that view cultures from Africa as barbaric, naïve, second rate and lacking civilization and devoid of vision and development (Kang'ethe, 2009, 2013). Realistically, literature indicates that female circumcision practice is recorded in Europe as early as 64BCE. It is reported in Europe and the United States of America as a therapy of treatment for insanity and masturbation (Wikipedia, 2014). On female circumcision in the US, Rodriguez writes that:

'In the United States, the first documented use of female circumcision as a sexual enhancement therapy occurred in the late 19th century, appearing at the time when the espousal of female orgasm during marital sex was increasingly seen as an important component for a healthy marriage...practitioners who removed clitoral hoods to enable female 
orgasm...presented evidence for the benefit of female circumcision at the meeting of American Medical Association in 1899. This procedure continued to be used to treat women for their inability to achieve orgasm throughout the 20th century'.

Rodriguez further observes that while there has been spirited campaign by feminists and medical practitioners since the 1970s to demean and condescend the practice, there is still evidence that the surgery to remove the hood of the clitoris as a sexual enhancement process still continues. Rodriguez's book on Female Circumcision and cliteridectonomy in the United States: A history of medical treatment now in print is due for release in October 2014. Will probably add to further locating the niche of female circumcision in mankind. This information is very important as it serves to disabuse the notion that female circumcision is a practice to be found only in communities that are 'barbaric' and less civilized.

\subsection{Conceptualizing female circumcision from African western- based scholars}

Perhaps the succinct voice of the "insiders", whether living in Africa, or elsewhere, who own and understand the practice of female circumcision can help clear the minds of many people whose minds have been spoilt with the result of only knowing and reflecting only what the "outsiders" have presented, whether in print or electronic media, or in any other forums of discourses. Perhaps those who adhere and therefore own the practice and are therefore reliable voices pertaining to the practice understand that the concept of female circumcision forms a rite of passage that encapsulates the attainment, enhancement, and maintenance of many cultural roles (Kang'ethe \& Rhakudu, 2010;Prazak 2007; Nnaemeka 2005; Gruenbaum 2001; Shweder 2000; Ahmadu 2000; Obermeyer 1999; Mbiti 1969; Kenyatta, 1948). The circumcision or operation on the genitalia is symbolic of the more detailed processes that form this rite of passage (Wodenmicael, 2009 Ahmadu 2000). This is also true of the male circumcision that has perhaps attracted many adherents in the globe than female circumcision (Wodenmicael, 2009; Kang'ethe, 2013; Ntombela, 2011). Talking of male and female circumcision as a mere removal of the foreskin and the clitoris respectively is a misnomer. Revealingly, the structure of both male and female circumcision is more elaborate than most of the existing literature has been able to capture. It is succinctly certain that discourse on African circumcision badly requires re-examination, reflection and possibly introspection in view of the fact that most of the current discourses tend to overlook the more important processes that embeds this rite of passage. The state of immense social capital inherent with the rite has unfortunately been obscured (Kang'ethe, 2013, 2014a; Ahmadu 2000; Obermeyer 1999). Perhaps this is because of the fact that the world has been fed by the "outsider voices", with "insider voices" given a raw deal. This is because of inadequate engagement of patriotic and culturally pragmatic scholars to salvage the African cultures from decadence and extinction, if not total annihilation (Afolayan, 2004). However and optimistically, some western based scholars have risen to the challenge of defending the culture and its invaluability. To this end, Fuambai Ahmadu, a Sierra Leonean scholar resident in America but who came home to go through the rite observed that:

it is difficult for me-considering the number of ceremonies I have observed, including my own-to accept that what appear to be expressions of joy and ecstatic celebrations of womanhood in actuality disguise hidden experiences of coercion and subjugation. Indeed, I offer that the bulk of Kono women who uphold these rituals do so because they want to- they relish the supernatural powers of their ritual leaders over against men in society, and they brace the legitimacy of female authority and, particularly, the authority of their mothers and grandmothers' (Ahmadu, 2000).

Arguably, the experience and views of Ahmadu are applicable to her ethnic group in Sierra Leone and may be equally applicable in the other settings in Africa such as the Sudan where a similar rite of passage is practiced. The statement, however, underscores some important facts on ownership, niche and the meaning grounded in female circumcision in Africa. The practice is full of immeasurable social capital that can only be communicated to the world by those who experience the practice, are patriotic enough and those who have stood the test of their times to be counted as not having fallen into the imperialistic trap or carried by the wind of Eurocentric whims and ideals (Ahmadu 2000). The process is a blissful one, ritualistic and is not necessarily a product of patriarchy (Wodenmicael, 2009; Ntombela, 2011; Ahmadu, 2000). These cultural architects would wish that those who share the same opinion, knowledge and insights such as Ahmadu above could grab any opportunity either in print or electronic media to disabuse the skewed and fallacious information surrounding female circumcision. 


\subsection{Female circumcision goes beyond spilling of blood}

Indubitably, these cultural architects believe that the sanctity, truths and insights surrounding cultures can only be told by the insiders. The outsiders may mimic but they may not communicate the real issues (Afolayan, 2004). In many settings in which the rite of female circumcision is practised, the rite is more than spilling of the young females' blood and causing them harm and pain as the western scholars, feminists, human rights activists and the western governments, nongovernmental agencies, and the media are trying to portray to the world (Kenyatta, 1948; Ahmadu; Prazak 2007). There are more elaborate activities and learning sessions in the course of the rite. An equally important point from Ahmadu's observation is the ownership of the process of female circumcision by women themselves contrary to what has been claimed by western feminists that such practices respond to patriarchy (Mbiti, 1969). To this end, most of the literature on the rite of passage tends to fallaciously concentrate on the "cutting part" and obscuring or ignoring other important meanings grounded in the rite. Such information also disregards ethical consideration in that it is more often passed to the world without the consent of the girls and the next of kins involved.

\subsection{Conceptualization, still an outsider perspective}

Evidently, most of the current discourse on female circumcision in Africa suffers immensely from the lack of insiders' view on the structure and significance of this rite of passage. Inarguably, the domain of African female circumcision has been unfairly a "babe" of the west, a babe they did not bear, nor knew how to wean, yet claiming to replace the actual mother. It is high time the "babe" is given back to its rightful owners, to suck and wean. It is the owners who should report on the morphology and characteristics of the "babe" and what it means to them so that they can tell the world the meaning from their inside. This misplaced handling of the culture of female circumcision could largely explain why some scholars, mostly from the west loudly and unashamedly indicate that the culture needs to be driven to a state of extinction and that those who dare continue the practice need to face the full wrath of human based rights and legislature. Fallaciously, the owners of the culture, or as proverbially indicated above "the owners of the babe" have been assumed to be passive to accept the verdict, without any resistance or any form of appeal. This explains "the cat and mouse" battles that has been going on between the law enforcement officers and cultural adherents in some countries where the norm has persisted though clandestinely. Kenya, forms such a good example of the scenario (Prazak 2007, Kiplagat, 2014). Such imperialistic and autocratic approach to cultures the West cannot fathom and understand has in itself disregarded the cultural rights of societies enshrined in many constitutions of the world as well as in the Bill of rights (Barnett-Grant et al, 2001; Vincent, 2006).

Perhaps it is this premise of the outsider perspective that has brought in different perfidious connotations of the practice. First and foremost, it has been branded as barbaric and not attuned to the culture of any 'developed' world. Also the outsiders have "baptized" the practice as female genital cutting, female genital mutilation, torture etc. (Ahmadu, 2000; Kamara-Fredericks, 2014). These cultural architects use this forum to ask for appropriate titles of the practice if at all it requires any name branding. They are of the view that culture should referred to as a surgery or an operation. This argument should not be viewed as a new war by a few Afrocentric scholars that we represent, but a rather as a discourse aimed at attaining cultural identity, cultural autonomy and independence and emancipation, cultural realism, cultural revival, cultural renaissance and cultural emancipation and repositioning it to take its rightful niche (Kang'ethe, 2014d; Afolayan, 2004). The discourse has become a bone of contention between universalists, human rights activists and cultural relativists.

\subsection{Female circumcision could be a tool of fighting HIVIAIDS and moral decadence}

Perhaps it is good to indicate how the practice could contribute to the current global agenda of fighting ills such as HIVIAIDS and state of moral decadence (Kang'ethe \& Khayundi, 2014). In tandem with male circumcision, the practices are believed to have an impact on behavioural change that is necessary to tame the tide of the HIVIAIDS and sexually transmitted diseases especially in African countries south of Sahara (Ramphele, 2008; Kang'ethe \& Khayundi, 2014; Yount \& Abraham 2007, Stallings \& Karugendo, 2005). Perhaps this is because the rites are supposed to be accompanied by a lot of lessons and counselling. In some cases, the initiates make oath promising to abide with the societal norms and expectations. In the world of increased state of moral decadence which these cultural architects believe has an inextricable relationship with the prevalence of HIVIAIDS, these rites could form a platform to benchmark and advocate for strong moral and ethical grounding. With the western pragmatists and WHO (WHO, 2002) urging Africans to consider "going back to their roots" in an endeavour to look for their home brewed solutions to their 
innumerable socio-economic challenges, these cultural architects boldly indicate that repositioning, rejuvenating and bolstering these cultural practices is critical and long overdue (Kang'ethe, 2014d). While these architects appreciate and welcome the westerners for initiating and championing the campaign of male circumcision as a solution to HIVIAIDS (Peltzer et al, 2008; Kang'ethe, 2013) and they have invested heavily in the project, they should also support the Africans to Africanize most of their cultures such as female circumcision and virginity testing (Kang'ethe, 2014b; Kang'ethe \& Khayundi, 2014). They should let the African themselves explain the meaning embedded in them. It is imperialistic and an act of condescension to make decisions or pave the direction of a culture without the genuine participation of the owners. It constitutes a human rights disdain.

\section{The Way Forward}

- African governments should allow its people to enjoy their cultural rights. All what the governments should do is to facilitate the safety and hygiene of the cultural practices. Also the governments should not mimic the imperialistic and autocratic dispensation of the western based governments to decide the fate of the African cultures.

- The adherents of many cultures that are being outlawed need to be flexible to change some aspects of the cultures that are retrogressive. Some cultural goals posts need to shift without changing the social capital and meaning embedded in them

- The culture of female circumcision should not be referred as female genital cutting, torture or mutilation. It is a surgery or operation

- Holistic research needs to be unleashed in the domain so that the social capital embedded in the culture of female circumcision is unearthed and proper documentation and dissemination is done

\section{Conclusion}

African governments should stop being oppressive to the cultures of its people by agreeing by the western countries to do away some cultures that the west has branded "anti-developmental, anti-visionary, barbaric, naïve and those reminiscent of stone age epoch. These are sentiments meant to undermine the integrity of the Africans. It is unfortunate that it is mostly the elites who have fallen into this unfortunate trap. Governments should know that development and modernization does not mean demeaning and condescending cultures. Perhaps African governments need to learn from countries such as Japan that has maintained its cultures in tandem with the scope of development. The culture of female circumcision should be given all the dignity it deserves, its immense social capital it stands for needs to be appreciated, but only if governments lift their ban on it. The fact that the culture has been associated with some clinical hazards or mishaps is not good reason enough to take away people's democratic and cultural dispensation to practice it. Perhaps making arrangements to reduce such hazards and mishaps would be critical in cleaning the culture. These cultural architects believe that with the ravaging waves of social ills such as HIVIAIDS and moral decadence, cultures such as female circumcision could play a significant role in effectuating behavioural change. This is a wakeup call, therefore for scholars and cultural architects to appreciate the new dawn of cultural revival, cultural renaissance, cultural autonomy and cultural emancipation, to position and reposition cultures such as female circumcision in their rightful niche.

\section{References}

Afolayan, F. (2004) Culture and Customs of South Africa. Wesport, Connectticut: Greenwood Press.

Ahmadu, F (2000) 'Rites and wrongs': An insider/outsider reflects on power and excision. [Online] Available : http://africanholocaust.net/ fgm.html. Date 08/08/2014

Barrett-Grant, K., Fine, D., Heywood, M. \& Strode, A. (eds.) (2001). HIV/AIDS and the Law: A Resource Manual (2nd edition). Johannesburg, South Africa, The AIDS Law Project and The AIDS Legal Network, University of the Witwatersrand.

Boyle, EH \& Corl, AC (2010). Law and culture in a global context: Interventions to eradicate female genital cutting. Annual Review of Law and Social Sciences .Vol. 6: 195-215.

deVries, C (2013). Debunking myths about female circumcision. African Journal of Urology Vol. 19: 143-144

Edouard, E., Olatunbosun, O., \& Edouard, L. ( 2013). International efforts on abandoning genital mutilation. African Journal of Urology Vol. 19: 150-153

Gruenbam, E (2001). The female circumcision controversy: An anthropological Perspective. Philadelphia: University of Pennsylvania Press

Gruenbaum, E (2005). Socio-cultural dynamics of female genital cutting: Research findings. Gaps and directions. Culture, Health and 
Culture. 7 (5). P 429-441.

Kamara-Frederick, J (2014). FGM is bad but it's not child abuse. Online at www.trust.org/item/2014513180055.

Kang'ethe S.M (2009). Traditional healers as caregivers to HIVIAID patients. Sahara journal. Vol. 6 (2). September, 2009. Pp.83-91.

Kang'ethe, S.M \& Rhakudu, M (2010). Religious Education book for form 2. Heinemann Publishers, Gaborone.

Kang'ethe, S.M (2013). The panacea and perfidy of cultural rites of circumcision in African countries: Examples from Kenya, Botswana and South Africa. EASSRR Journal. Vol. xxix, no 1, pp. 107-123.

Kang'ethe S.M (2014a). The panacea and perfidy of culture as a platform of behavior change with examples from Botswana and South Africa. In the press of Mediterranean journal of social sciences, Rome Italy. Vol 5, No 14. Page493-499.

Piaget, J. (1990). The child's conception of the world. New York. Littlefield Adams

Kang'ethe, S.M. (2014b). The need to resuscitate the cultural rite of virginity testing as a tool to strengthen the campaign against HIVIAIDS and moral decadence in South African region. Mediterranean Journal of Social Sciences. Vol .5, Number 8. Page 484489.

Kang'ethe, S.M (2014c). Social capital from informal networks can be a fertile niche to mitigate HIVIAIDS and poverty effects: Examples from South Africa and Botswana. Accepted for publication in the Journal of Human Ecology, India

Kang'ethe S.M (2014d). Repositioning, Reclaiming and Rejuvenating the Niche of Traditional Practitioners in the face of Modernization in selected African Countries. In the Press of Studies on Ethno-Medicine, India

Kang'ethe S.M \& Khayundi, F. (2014). The Dimensions, Perfidy and ramifications of teenage pregnancies with examples from a few countries of the globe. A literature review. Mediterranean Journal of Social sciences. Vol 5, No 15. Page .609-614

Kenyatta, J (1948). Facing Mount Kenya. Garden City. NY: Doubleday Publishing Group.

Kiplagat, R. ( 2014). Traditionalist: Female Genital Mutilation is holy. Standard Digital News. Online at http://www.standerdmedia.co. ke/m/article?article/ID2000128533 Date 18 July 2014.

Kratz, C (2003). Circumcision, pluralism and dilemmas of cultural relativism. In Applying Anthropology: An Introductory Reader. Edited by Aaron Podelefsky and Peter J. Brown. New York: McGraw Hill.

Lyons, HD (2007). Genital cutting: The past and present of a Polythetic Category. Africa Today. Vol.53 no. 4: 3-17.

Mbiti, J.S. (1969). African Religious Religions and philosophy. Nairobi. East African Educational Publishers.

Nnaemeka, O. (2005). Female circumcision and the politics of knowledge: African women imperialism discourses. Greenwood Publishing Group. USA

Ntombana, L. (2011). Should Xhosa male initiation be abolished? International journal of Cultural Studies 2011 14: 631: Sage

Obermeyer, C. (1990). Female genital surgeries: The known, the unknown and the unknowable. Medical Anthropology Quarterly Vol.13 : 79-106

Peltzer, K., Niang, C.I., Muula, A.S., Bowa, K., Okeke, L., Boiro, C., \& Chimbwete, C. (2007). Male circumcision, gender and HIV prevention in sub-Sahara Africa: A (Social Science) research agenda, Journal of Social Aspects of HIV/AIDS, Vol.4, No.3, November: 658-666.

Prazak, M. (2007). Introducing Alternative Rites of Passage. Online at http://www.jstor.org./stable/4187808. Accessed 23/07/2014

Rodriguez, S.B (2008) Rethinking the history of female circumcision and cliteridectonomy; American medicine and female sexuality in the late 19th century. Journal of History of Medicine and Allied sciences. Vol. 63 no 3: 323-347

Ramphele, M. (2008). Laying Ghosts to Rest. Dilemmas of the Transformation in South Africa. Cape Town: Tafelberg Report. Participatory Education, Evaluation and Research.

Shweder, RA (2000). What about genital mutilation? And why understanding culture matters in the first place. Daedalus Vol. 129 no.4 : 209-232

Stallings, RY \& Karugendo, E. ( 2005). Female circumcision and HIV infection in Tanzania: for better or for worse. Paper given at the $3 R D$ International AIDS society.

Vincent, L (2006). Virginity testing in South Africa: Re-traditioning the postcolony. Culture, Health and Sexuality Vol. 8 no. 1 : 17-30.

WHO (2002). Community home based care in resource-limited settings. A framework for action. 20 Avenue Appia, 1221 Geneva 27, Switzerland.

Wodenmicael, G (2009). Female genital cutting in contemporary Eriteria. Determinants, future prospects, and strategies for eradication. EASSRR, Vol XXV. No2. June 2009.

Yount, K. \& Abraham, B. ( 2007). Female genital cutting and HIVIAIDS among Kenyan women. Studies in Family Planning Vol. 38 no. 2 : 73-88.

Wikipedia (2014). Female genital mutilation. Online at http://en.wikipedia.org/wiki/female_genital_mutilation. 